\title{
Non-Structural Proteins from Human T-cell Leukemia Virus Type 1 in Cellular Membranes-Mechanisms for Viral Survivability and Proliferation
}

\author{
Elka R. Georgieva \\ Department of Chemistry and Chemical Biology, Cornell University, Ithaca, NY 14853, USA; \\ erg54@cornell.edu; Tel.: +1-607-255-4980
}

Received: 8 October 2018; Accepted: 6 November 2018; Published: 8 November 2018

check for updates

\begin{abstract}
Human T-cell leukemia virus type 1 (HTLV-1) is the causative agent of illnesses, such as adult T-cell leukemia/lymphoma, myelopathy/tropical spastic paraparesis (a neurodegenerative disorder), and other diseases. Therefore, HTLV-1 infection is a serious public health concern. Currently, diseases caused by HTLV-1 cannot be prevented or cured. Hence, there is a pressing need to comprehensively understand the mechanisms of HTLV-1 infection and intervention in host cell physiology. HTLV-1-encoded non-structural proteins that reside and function in the cellular membranes are of particular interest, because they alter cellular components, signaling pathways, and transcriptional mechanisms. Summarized herein is the current knowledge about the functions of the membrane-associated $\mathrm{p} 8^{\mathrm{I}}, \mathrm{p} 12^{\mathrm{I}}$, and $\mathrm{p} 13^{\mathrm{II}}$ regulatory non-structural proteins. $\mathrm{p} 12^{\mathrm{I}}$ resides in endomembranes and interacts with host proteins on the pathways of signal transduction, thus preventing immune responses to the virus. $\mathrm{p} 8^{\mathrm{I}}$ is a proteolytic product of $\mathrm{p} 12^{\mathrm{I}}$ residing in the plasma membrane, where it contributes to T-cell deactivation and participates in cellular conduits, enhancing virus transmission. $\mathrm{p} 13^{\mathrm{II}}$ associates with the inner mitochondrial membrane, where it is proposed to function as a potassium channel. Potassium influx through $\mathrm{p} 13^{\mathrm{II}}$ in the matrix causes membrane depolarization and triggers processes that lead to either T-cell activation or cell death through apoptosis.
\end{abstract}

Keywords: T-cell leukemia virus type 1 ; $\mathrm{p} 8^{\mathrm{I}}$ protein; $\mathrm{p} 12^{\mathrm{I}}$ protein; $\mathrm{p} 13^{\mathrm{II}}$ protein; virus-host interactions; viral non-structural proteins; cellular membranes

\section{Introduction}

Human T-cell leukemia virus type 1 (HTLV-1) is the etiological agent of adult T-cell leukemia/lymphoma (ATLL) and HTLV-1-associated myelopathy/tropical spastic paraparesis (HAM/TSP) [1-4]. HTLV-1 almost exclusively infects CD4 ${ }^{+}$T cells, which are key in the modulation of immune responses to pathogens and tumor cells [5,6]. ATLL affects the blood, central nervous system, bone, and other visceral sites $[7,8]$ and is an aggressive and invariably fatal disease with a survival time of less than 1 year $[2,9,10]$. HAM/TSP is an irreversibly progressive neurological disease characterized by demyelinating lesions in the brain and spinal cord. These lesions result in motor disorders and a low quality of life [11-13]. HTLV-1 is also associated with infective dermatitis and Sjögren's syndrome (immune and endocrine-metabolic disorders), as well as thyroiditis and other diseases $[10,14]$.

HTLV-1 was the first human retrovirus discovered as a result of extensive studies to identify the causative agent(s) of ATLL $[1,15,16]$. It was first isolated from a patient with cutaneous T-cell lymphoma [16]. HTLV-1 can be transmitted through biological fluids [17-19]. Other retroviridae family members, which are HTLV-2 [20], HTLV-3 [21], HTLV-4 [22], and HIV [23], were subsequently identified. Of these, only HTLV-2 can cause neurological disorders, some of which resemble HAM/TSP-although 
with a very low probability $[24,25]$ —and immortalize normal human peripheral blood cells via co-cultivation with pre-infected donor cells in a manner similar to that of HTLV-1 [15,26,27]. Strikingly, among all HTLVs, only HTLV-1 causes malignant transformations in T cells in vivo, which is indicative of its unique mechanisms of infection leading to ATLL [28].

Worldwide, an estimated 10-20 million people are infected with HTLV-1 [29,30], although a recent study reports a smaller number of 5-10 million [31]. Among HTLV-1 carriers, 5-10\% develop either ATLL or HAM/TSP [32-34]. Despite the devastating and often fatal impact of these viruses on human health, no means of controlling the spread of HTLV-1 or curing its associated diseases have been developed. The understanding of the mechanisms used by the virus to preclude its recognition and destruction by natural killer (NK) cells and cytotoxic T cells responsible for the control of viral infections in the body is largely insufficient [4,35-37]. HTLV-1 infection is usually asymptomatic, and the early assumption was that it could remain latent for decades [4,38]. However, chronically active cytotoxic T-cell responses to HTLV-1 antigens have been detected in all infected individuals, which suggests that the virus is not completely latent $[34,39]$.

It is currently thought that in this continuing asymptomatic state, only the HTLV-1 plus-strand is latent, whereas the transcription of the minus-strand is active, resulting in the low-level expression of the HTLV-1-encoded protein basic leucine zipper factor (HBZ) [34]. Low concentrations of HBZ and its reduced affinity to the free major histocompatibility complex class I (MHC-1) preclude the immune response to the virus [40]. HTLV-1 functioning in the cell requires the expression of plus-strand-encoded proteins, which have essential roles. The factors regulating the transcription of HTLV-1 plus-strand and the interplay between the plus- and minus-strand transcriptions are not well understood. One possibility is that certain conditions, such as those in bone marrow, lymph, and lymph nodes, are optimal for virus activation and viral protein expression [34,41]. Owing to these uncertainties and deficiencies in both understanding of HTLV-1 physiology in the host and knowledge of factors triggering ATLL, HAM/TSP, and other HTLV-1-associated diseases, the cellular and molecular mechanisms of these diseases are poorly understood.

Specific interactions of the virus-encoded proteins with cellular components that modify cellular function and communication through signaling are critical for the adaptation and survival of the virus. Therefore, understanding of the functional mechanisms of proteins vital to the virus would allow for interventions affecting HTLV-1 infectivity and pathogenesis, guiding the development of viral protein inhibitors that could restrict the effects of viral proteins on cellular mechanisms and possibly restore cellular homeostasis. To this end, special attention should be paid to the HTLV-1-encoded non-structural proteins (NSPs), which are also known as "regulatory" or "accessory" proteins: p12I, p8 ${ }^{\mathrm{I}}, \mathrm{p} 30{ }^{\mathrm{II}}, \mathrm{p} 13^{\mathrm{II}}$, Rex, Tax, HBZ, and HBZ-SP1(SP2) [28]. These proteins are absent in the mature virions, but are expressed in the host cell, where they act by modifying signaling pathways and the permeability of cellular membranes, redistributing ions in cellular compartments, promoting the transcription of viral proteins, inhibiting DNA repair, and ultimately altering host cell homeostasis $[28,42-47]$. Thus, NSPs are versatile tools that aid HTLV-1 in escaping and disabling host immune responses, optimizing viral replication and proliferation, and in some cases immortalizing infected cells. These functions make NSPs one of the primary targets for the development of therapeutics to control HTLV-1 infection and HTLV-1-linked diseases.

This review focuses on the function of HTLV-1-encoded NSPs $\mathrm{p} 12^{\mathrm{I}}, \mathrm{p} 8^{\mathrm{I}}$, and $\mathrm{p} 13^{\mathrm{II}}$ in the membranes of infected cells. The $\mathrm{p} 12^{\mathrm{I}}$ and $\mathrm{p} 8^{\mathrm{I}}$ proteins reside in the endomembranes and plasma membrane, respectively, and are critical for the adaptation, survivability, and proliferation of the virus. $\mathrm{p} 13^{\mathrm{II}}$ associates with and self-aggregates in the inner mitochondrial membrane (IMM) to form a potassium $\left(\mathrm{K}^{+}\right)$channel. Through its channel activity, $\mathrm{p} 13^{\mathrm{II}}$ supports HTLV-1 survivability and proliferation in the host. The current knowledge and proposed mechanisms of these proteins' functions in the membranes of infected cells are summarized. 


\section{2. $\mathrm{p} 12^{\mathrm{I}}$ and $\mathrm{p} 8^{\mathrm{I}}$ Proteins and Their Roles in HTLV-1 Adaptation and Proliferation in the Host}

Open reading frame I (ORF-I) of the HTLV-1 genome encodes the $\mathrm{p} 12^{\mathrm{I}}$ protein. $\mathrm{p} 8^{\mathrm{I}}$ is derived from $\mathrm{p} 12^{\mathrm{I}}$ after a proteolytic cleavage at position G29/L30 (Figure 1A,B). These two protein forms, $\mathrm{p} 12^{\mathrm{I}}$ and $\mathrm{p} 8^{\mathrm{I}}$, have molecular weights of ca. $12 \mathrm{kDa}$ and $8 \mathrm{kDa}$ and lengths of 99 amino acids (aa) and 70 aa, respectively. Both proteins are highly hydrophobic, and both reside and function in the cellular membranes although with different localization. $\mathrm{p} 12^{\mathrm{I}}$ resides in the membranes of the endoplasmic reticulum (ER) and cis-Golgi apparatus, whereas upon removal of the non-canonical ER retention/retrieval signal sequence in the $\mathrm{N}$-terminal region of $\mathrm{p} 12^{\mathrm{I}}$ (Figure 1B) $[48,49], \mathrm{p} 8^{\mathrm{I}}$ traffics to the plasma membrane, where it is found in lipid rafts at the immunological synapse [48,50].

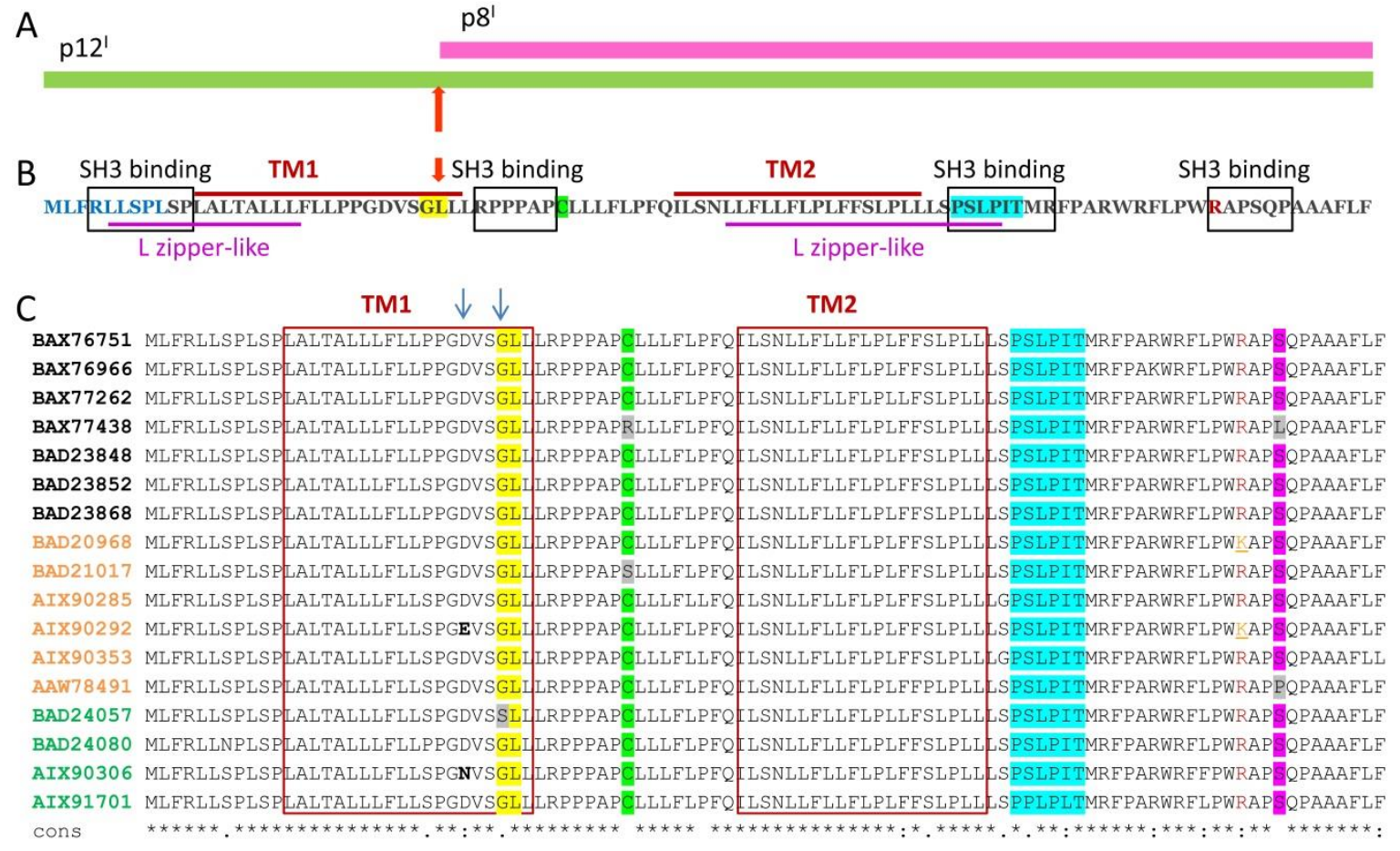

Figure 1. $\mathrm{p} 12^{\mathrm{I}}$ and $\mathrm{p} 8^{\mathrm{I}}$ proteins' organization: (A) $\mathrm{p} 8^{\mathrm{I}}$ is a proteolytic product of $12 \mathrm{I}$; the proteolytic cleavage site G29/L30 is indicated with an arrow; (B) aa sequence and putative domain architecture of full length $\mathrm{p} 12^{\mathrm{I}}$ are shown: The endoplasmic reticulum (ER) retention $\mathrm{N}$-terminal sequence is in blue; The transmembrane helices TM1 and TM2 are designated with red bars above the sequence; SH3 binding motifs are in black rectangles; L zipper-like motifs are underlined in magenta; R88 is in red; the G29/L30 cleavage site is highlighted in yellow and indicated by a red arrow. (C) Alignment of multiple aa sequences of $\mathrm{p} 12^{\mathrm{I}}$ from randomly selected HTLV-1 strains, which were isolated from human carriers: Protein identification numbers in black, orange and green are from patients with adult T-cell leukemia/lymphoma (ATLL), patients with HTLV-1-associated myelopathy/tropical spastic paraparesis (HAM/TSP) and asymptomatic carriers, respectively. Conserved aa are indicated with asterisks under the sequences; residues D26 and G29 and their substitutions that are relevant to the level of $\mathrm{p} 12^{\mathrm{I}}$ and $\mathrm{p} 8{ }^{\mathrm{I}}$ co-expression, are indicated with arrows; the cleavage site G29/L30, C39, the calcineurin binding motif, and residue S91, which is frequently mutated to other aa (mostly to P91), are highlighted in yellow, green blue, and magenta respectively; TM1 and TM2 are in red rectangles. The substitutions G29S, C39S, C39R, S91L, and S91P are highlighted in grey; R88 and K88 are in red and orange, respectively. T-COFFEE Multiple Sequence Alignment software was used.

ORF-I knockout viruses are not infectious in non-human primates [51], which points to the significant roles of ORF-I encoded proteins. Rabbits infected with a $\mathrm{p} 12^{\mathrm{I}}$-deficient molecular clone of HTLV-1 showed reduced viral infectivity compared with those infected with a p12 ${ }^{\mathrm{I}}$-encoding clone [52]. p12 ${ }^{\mathrm{I}}$ is expressed early after viral entry into the host cell and is essential for maintaining 
infection [52,53]. Multiple critical roles of $\mathrm{p} 12^{\mathrm{I}}$ and $\mathrm{p} 8^{\mathrm{I}}$ in maintaining and spreading the virus in host organisms have been reported.

p12 ${ }^{\mathrm{I}}$ has two predicted transmembrane (TM) helices, TM1 and TM2 (Figure 1B,C) [49], with N-and C-termini located on the cytoplasmic side [49]; four SRC homology 3 domain (SH3) binding motifs (PXXP) [54], which are important for interactions with other proteins involved in intracellular signaling [55,56]; and leucine (L) zipper-like regions, through which the protein forms dimers in membranes [57]. Some studies have found that $\mathrm{p} 12^{\mathrm{I}}$ dimerization is due to the formation of a disulfide bond through the conserved cysteine residue at position 39 (C39) (Figure 1); when this residue is palmitoylated, the protein remains monomeric $[57,58]$. C39 palmitoylation has been suggested to be critical for ATLL transmission [58]. However, some HTLV-1 strains encode $\mathrm{p} 12^{\mathrm{I}} / \mathrm{p} 8^{\mathrm{I}}$ proteins that have a C39 substitution for serine (S39) or arginine (R39) (Figure 1B). Therefore, the precise role of this residue in $\mathrm{p} 12^{\mathrm{I}} / \mathrm{p} 8^{\mathrm{I}}$ assembly and function remains to be established. The presence of a lysine residue at position 88 (K88) decreases protein stability, as it is susceptible to ubiquitination, but an arginine at this position (R88) has a stabilizing effect [57]. R88 is present in $\mathrm{p} 12^{\mathrm{I}}$ isolated from HTLV-1 strains found in asymptomatic carriers and patients with ATLL, whereas K88 is found in some of the strains isolated from patients with HAM/TSP. Therefore, this residue might be relevant to the type of pathology caused by HTLV-1 [57].

$\mathrm{p} 12^{\mathrm{I}}\left(\right.$ also $\mathrm{p} 8^{\mathrm{I}}$ ) is a highly conserved protein (Figure 1B). However, analysis of 834 patient-isolated HTLV-1 DNA sequences identified multiple aa substitutions among $\mathrm{p} 12^{\mathrm{I}} / \mathrm{p} 8^{\mathrm{I}}$ homologues of various HTLV-1 strains [59]. Of these, the G29S, P34L, S63P, R88K, and S91P substitutions were the most frequent mutations with possible implications for virus adaptation and proliferation in the cell. The glycine-to-serine (G29S) mutation results in the expression of non-cleavable p12 ${ }^{\mathrm{I}}[48,49,60]$, whereas a rare mutation of aspartic acid (D) in position 26 to either asparagine $(\mathrm{N})$ or glutamic acid (E) results in the predominant expression of $\mathrm{p} 8^{\mathrm{I}}$ [48]. These mutations have been exploited to assess whether $\mathrm{p} 8^{\mathrm{I}}$ and $\mathrm{p} 12^{\mathrm{I}}$ expression is required for viral infectivity and persistence in macaques inoculated with B-cell lines that were transfected with HTLV-1 molecular clones carrying G29 and D26 aa's, as well as mutants with either G29S or D26N substitutions [59]. No virus infectivity was observed when only the $\mathrm{p} 12^{\mathrm{I}}$ with G29S substitution was expressed. Furthermore, the abundance of $\mathrm{p} 8{ }^{\mathrm{I}}$ alone (D26N mutant) limited viral persistence [59], and the absence of both $\mathrm{p} 8^{\mathrm{I}}$ and $\mathrm{p} 12^{\mathrm{I}}$ increased the susceptibility of HTLV-1-infected CD4+ T cells to T-killer cells [59]. These finding suggest that the synchronized expression of $\mathrm{p} 12^{\mathrm{I}}$ and $\mathrm{p} 8^{\mathrm{I}}$ is necessary for persistent HTLV-1 infection.

\subsection{Roles and Functional Mechanisms of $p 12^{I}$ in the ER}

p12 ${ }^{\mathrm{I}}$ enhances T-cell growth and proliferation in an interleukin-2 (IL-2)-independent manner [61,62]. IL-2 promotes T-cell proliferation and controls T-cell immune responses through the downregulation of signaling cascades [63]. These functions of IL-2 are directly dependent on its association with the IL-2 receptor (IL-2R), which is composed of three subunits: Alpha $(\alpha)$, beta ( $\beta$ ), and gamma $\left(\gamma_{c}\right)$. In the plasma membrane, the initial binding of IL-2 to the IL-2R $\alpha$-subunit further recruits the $\beta$ and $\gamma_{c}$ subunits to form a tertiary IL-2/IL-2R complex [64]. Co-immunoprecipitation experiments have provided evidence that $\mathrm{p} 12^{\mathrm{I}}$ binds specifically to the IL-2R $\beta$ and $\gamma_{\mathrm{c}}$ subunits; however, the binding occurs exclusively with the immature forms of the subunits in the pre-Golgi compartments [62]. Thus, $\mathrm{p} 12^{\mathrm{I}}$ has an immunosuppressive role in that it prevents the maturation and trafficking of the $\beta$ and $\gamma_{c}$ subunits to the cell surface and thus inhibits the formation of a functional IL-2/IL-2R complex (Figure 2A). In doing so, $\mathrm{p} 12^{\mathrm{I}}$ also redirects the signaling pathway of T-cell activation. On the plasma membrane of uninfected T cells, the $\beta-\gamma_{\mathrm{c}}$ heterodimer recruits and activates the signal transducer and activator of transcription 5 (STAT5) protein, resulting in the expression of IL-2 and the activation and proliferation of T cells [65]. However, this pathway is restricted in HTLV-1-infected cells expressing p12 ${ }^{\mathrm{I}}$. Nonetheless, the co-localization of the $\beta$ and $\gamma_{\mathrm{c}}$ subunits upon binding to $\mathrm{p} 12^{\mathrm{I}}$ also enhances STAT5 phosphorylation, leading to its activation and providing an efficient tool for viral control of T-cell proliferation without the need for IL-2 [61] (Figure 2A). This could 
be a mechanism of oncogenesis given that studies have established that STAT5 is activated in $70 \%$ of ATLL primary cells [66]. Moreover, activated STAT proteins are hallmarks of other cancers $[67,68]$.
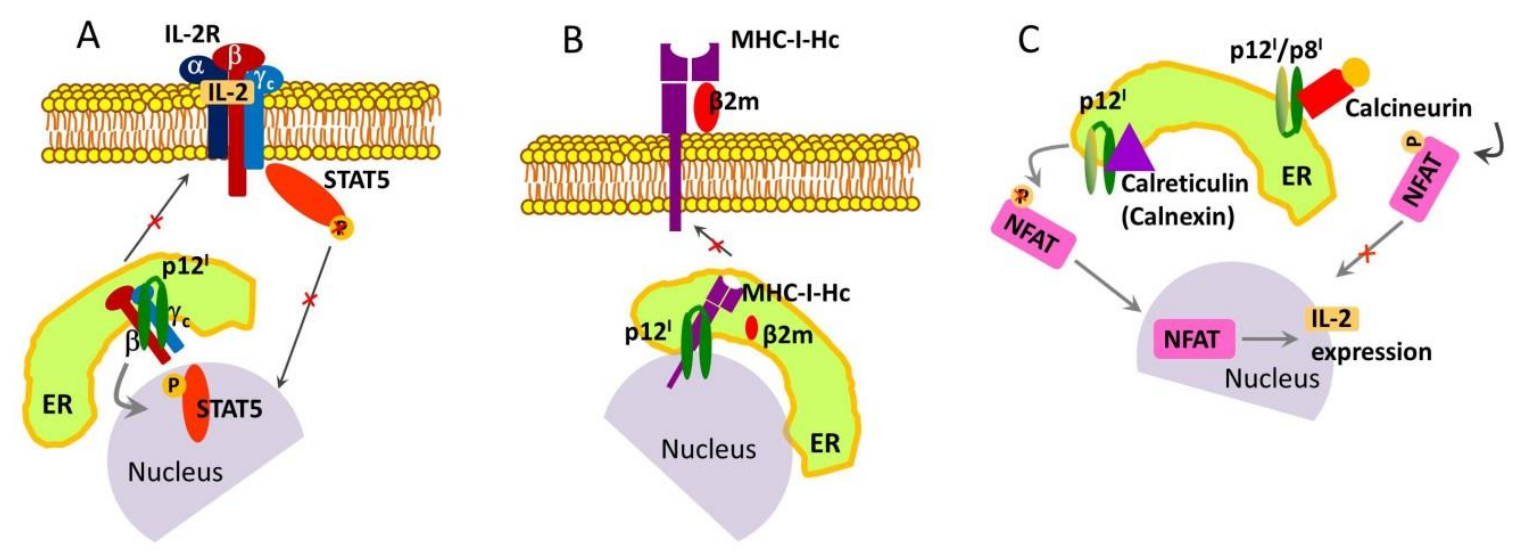

Figure 2. Mechanisms of $\mathrm{p} 12^{\mathrm{I}}$ in the endoplasmic reticulum (ER) of infected cells: (A) p12 ${ }^{\mathrm{I}}$ binds to the immature forms of interleukin-2 receptor (IL-2R) $\beta$ and $\gamma c$ subunits preventing their traffic to the plasma membrane and the assembly of IL-2/IL-2R complex, and hence, inhibits signal transducer and activator of transcription 5 (STAT5) activation. However, upon binding to $\mathrm{p} 12^{\mathrm{I}}$, the $\beta$ and $\gamma \mathrm{c}$ subunits co-localize and provide new way for STAT5 phosphorylation and activation. Thus, $\mathrm{p} 12^{\mathrm{I}}$ re-routes the STAT5 signaling pathway. (B) Through binding to the free human MHC-I heavy chain (MHC-I-Hc), p12 $\mathrm{I}$ obliterates the assembly of functional MHC-I-Hc- $\beta 2 \mathrm{~m}$ complex in the plasma membrane resulting in suppression of immune response. $(C)$ p12 ${ }^{\mathrm{I}}$ has a mechanism to increase the concertation of $\mathrm{Ca}^{2+}$ in the cytoplasm while depleting $\mathrm{Ca}^{2+}$ from the ER, which affects the $\mathrm{Ca}^{2+}$ signaling in the cell. To do so, p12 ${ }^{\mathrm{I}}$ interacts with host proteins (calreticulin and calnexin), which modulate $\mathrm{Ca}^{2+}$ storage. As a result, dephosphorylated nuclear factor of T cells (NFAT) migrates to the nucleus and induces IL-2 expression and T-cell activation. Other possible role is that $\mathrm{p} 12^{\mathrm{I}}$ interacts with calcineurin, thus inhibiting NFAT.

p12 ${ }^{\mathrm{I}}$ binds to the free human MHC-I heavy chain (MHC-I-Hc), as established in another co-immunoprecipitation assay [69]. The MHC-I complex plays a critical role in immunity: In infected cells, it binds peptide fragments derived from pathogens (e.g., viruses and bacteria) and displays them on the cell surface for recognition by $\mathrm{T}$ cells $[70,71]$. As a result, the $\mathrm{T}$ cells are activated and eradicate the infected cells. The MHC-I complex is composed of a transmembrane glycoprotein Hc, the $\beta 2$-microglobulin $(\beta 2 \mathrm{~m})$ [71]. $\mathrm{p} 12^{\mathrm{I}}$ has been found to associate with MHC-I-Hc but not with the entire MHC-I-Hc- $\beta 2 \mathrm{~m}$ complex [69] (Figure $2 \mathrm{~B}$ ). Furthermore, it has been suggested that in the ER, $\mathrm{p} 12^{\mathrm{I}}$ binds to a form of MHC-I-Hc that is not fully matured (most likely a less glycosylated form per the results of an electrophoresis assay) and obliterates the formation of the functional MHC-I-Hc- $\beta 2 \mathrm{~m}$ complex [69]. Preventing the T-cell recognition of invaded somatic cells in infected individuals may be a mechanism through which HTLV-1 suppresses immune response.

Another role of $\mathrm{p} 12^{\mathrm{I}}$ is to downregulate intercellular adhesion molecules I and II (ICAM-1 and ICAM-2) [46], which are ligands that activate the cytotoxic response of NK cells. As a result, NK cells cannot destroy HTLV-1-infected CD4 ${ }^{+}$T cells even though they show reduced surface expression of the MHC-I complex and therefore constitute a target of NK cells [46]. Thus, in addition to using the mechanism of suppressing MHC-I-mediated immune response, HTLV-1 may have evolved a means of making infected cells unsusceptible to NK-cell-controlled cytolysis. Another possibility is that through ICAM-1 downregulation $\mathrm{p} 12^{\mathrm{I}}$ obstructs T-cell activation, since ICAM-1 is a signaling molecule in this process [72]. However, the exact physiological effect of ICAM-1 downregulation by $\mathrm{p} 12^{\mathrm{I}}$ is unknown, because ICAM-1 expression is enhanced in Tax-producing cells [73], as well as in HTLV-1-positive cell lines and ATLL cells from patients [74] that might minimize the effect of $\mathrm{p} 12^{\mathrm{I}}$. 
Other studies have suggested that the $\mathrm{p} 12^{\mathrm{I}}$ protein increases the concentration of calcium ions $\left(\mathrm{Ca}^{2+}\right)$ in the cytoplasm and concurrently reduces the amount of $\mathrm{Ca}^{2+}$ available for release from the ER, thereby enhancing T-cell activation by modulating $\mathrm{Ca}^{2+}$ signaling [75]. Increased cytosolic $\mathrm{Ca}^{2+}$ activates the phosphatase calcineurin, which dephosphorylates the nuclear factor of $\mathrm{T}$ cells (NFAT) [76]. Dephosphorylated NFAT migrates to the nucleus and induces the expression of IL-2 [77], which leads to T-cell activation. A possible mechanism of $\mathrm{p} 12^{\mathrm{I}}$-induced cytosolic $\mathrm{Ca}^{2+}$ increase is through binding to the host proteins [78], which modulate $\mathrm{Ca}^{2+}$ storage, such as calreticulin and calnexin [79] (Figure 2C). This hypothesis is supported by the observation that $\mathrm{p} 12^{\mathrm{I}}$-induced NFAT activation is decreased in cells co-transfected with $\mathrm{p} 12^{\mathrm{I}}$ and increased doses of calreticulin [75]. Furthermore, the activation of $\mathrm{Ca}^{2+}$ influx channels in the plasma membrane contributes to the increase in cytosolic $\mathrm{Ca}^{2+}$ [75]. On the contrary, another possible role of $\mathrm{p} 12^{\mathrm{I}}$ may be to inhibit the function of NFAT through tight binding to calcineurin (Figure 2C), thereby leading to T-cell inactivation- $\mathrm{p} 12^{\mathrm{I}}$ has a calcineurin-binding motif in its C-terminal soluble domain (Figure 1B,C), which is homologous to the calcineurin-binding motif in NFAT [80]. Thus, similar to other proteins, such as the myocyte-enriched calcineurin-interacting proteins and A238L from African swine fever virus $[81,82], \mathrm{p} 12^{\mathrm{I}}$ might act as a negative regulator of NFAT and possibly other calcineurin-mediated physiological processes by binding to calcineurin. However, because $\mathrm{p} 12^{\mathrm{I}}$ and $\mathrm{p} 8^{\mathrm{I}}$ share the same C-terminal sequence located in the cytosol (Figure 1) [49], it is currently unclear whether only one of them or both interact with calcineurin. Furthermore, because calcineurin regulates protein activity through protein-protein interactions and phosphatase activity $(62,63), \mathrm{p} 12^{\mathrm{I}}$ (and $\mathrm{p} 8^{\mathrm{I}}$ ) may be a substrate of calcineurin if it undergoes phosphorylation/dephosphorylation in vivo, which has yet to be determined (64). It should also be mentioned that at present, there is no clear understanding of how and under what conditions $\mathrm{p} 12^{\mathrm{I}}$ acts as a T-cell activator or inactivator by modulating $\mathrm{Ca}^{2+}$ levels and calcineurin activity, thus regulating the NFAT phosphorylation state. The dual role of $\mathrm{p} 12^{\mathrm{I}}$ in T-cell activation/inactivation is similar to that of Bcl-2 protein when it resides in the ER membrane, the mechanism of which is also unresolved $[83,84]$.

\subsection{Roles and Functional Mechanisms of $p 8^{I}$ in the Plasma Membrane}

$\mathrm{p} 8^{\mathrm{I}}$ may provide another avenue to T-cell inactivation. It has been found that $\mathrm{p} 8^{\mathrm{I}}$ downregulates the transduction of proximal T-cell receptor signaling [48,50]. When localized at the immunological synapse in the plasma membrane, $\mathrm{p} 8^{\mathrm{I}}$ inhibits the signaling cascade leading to T-cell activation when in contact with antigen-presenting cells $[85,86]$. To do so, $\mathrm{p} 8^{\mathrm{I}}$ interacts with the protein called linker for activation of T cells (LAT) and decreases LAT phosphorylation, which results in decreased phosphorylation of the downstream T-cell signaling proteins phospholipase $C$ and Vav and downregulation of NFAT activity (Figure 3) [60]. In this way, $\mathrm{p} 8^{\mathrm{I}}$ favors viral persistence by inhibiting the immune responsiveness of T cells. Conclusions about these $\mathrm{p} 8{ }^{\mathrm{I}}$ activities were made based on a study in Jurkat T cells expressing $\mathrm{p} 8^{\mathrm{I}}$ and an analysis of proteins and their post-translational modifications in cell lysates [60]. However, at the time of the study, nothing was known about $\mathrm{p} 8^{\mathrm{I}}$ as a cleavage product of $\mathrm{p} 12^{\mathrm{I}}$, which migrates to the cell membrane. Also, the study was conducted using cells transfected with the precursor $\mathrm{p} 12^{\mathrm{I}}$ protein. Therefore, the authors believed that $\mathrm{p} 12^{\mathrm{I}}$ was responsible for the observed effects. 


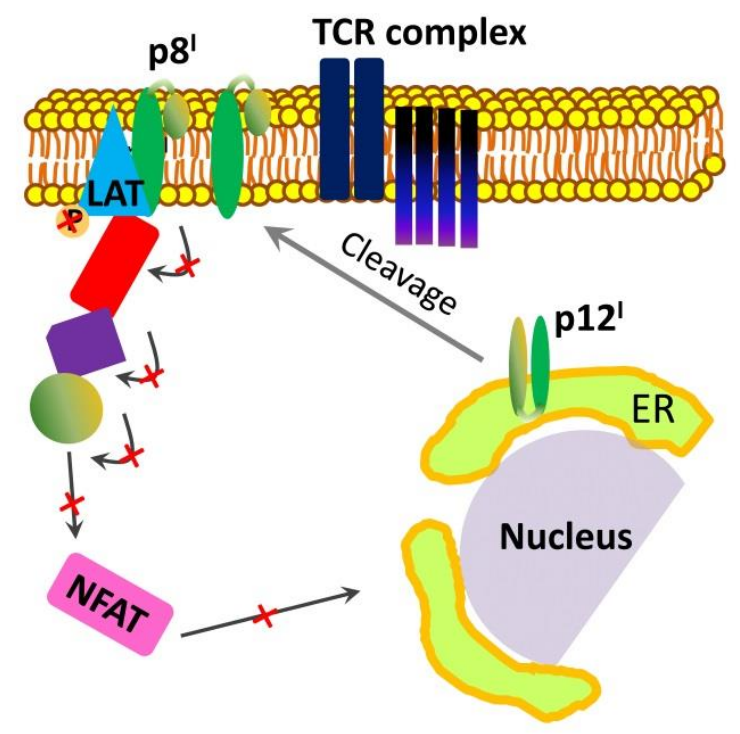

Figure 3. $\mathrm{p} 8^{\mathrm{I}}$ inhibits $\mathrm{T}$ cell receptor (TCR) signal transduction and NFAT activation: $\mathrm{p} 8^{\mathrm{I}}$ is a proteolytic product of $\mathrm{p} 12^{\mathrm{I}}$ in the ER membranes, the protein traffics to plasma membrane and localizes in the immunological synapse; $\mathrm{p} 8^{\mathrm{I}}$ interacts with and inhibits the phosphorylation of the transmembrane protein called linker for activation of T cells (LAT) and by doing so, $\mathrm{p} 8^{\mathrm{I}}$ disables LAT to transmit signals from TCR and to interact with other proteins, such as phospholipase C gamma 1, Vav proteins, and lymphocyte-specific protein tyrosine kinase (shown in red, cyan and green) on the TCR signaling pathway.

Further research found that in the plasma membrane, the activities of $\mathrm{p} 8^{\mathrm{I}}$ protein increase the number and length of cellular conduits, as well as the likelihood of virus transmission [43]. These findings were established in studies of $\mathrm{p} 8^{\mathrm{I}}$ expressed in Jurkat $\mathrm{T}$ cells: $\mathrm{p} 8^{\mathrm{I}}$ protein co-localizes with and increases the clustering of lymphocyte function-associated antigen-1 (LFA-1) and also enhances the contact between T cells through adhesion to clustered LFA-1. Furthermore, these studies demonstrated that $\mathrm{p} 8 \mathrm{I}$ increases T-cell contact among primary lymphocytes, as observed in peripheral blood mononuclear cells (PBMCs) and MT-2 cells overexpressing $\mathrm{p} 8{ }^{\mathrm{I}}$, in which conduits formed preferentially between resting PBMCs and MT-2 cells [43]. Notably, $\mathrm{p} 8^{\mathrm{I}}$ protein was visualized in these conduits. The increased conduit formation by $\mathrm{p} 8^{\mathrm{I}}$ was also confirmed in co-culturing experiments with non-transfected and $\mathrm{p} 8{ }^{\mathrm{I}}$-transfected Jurkat $\mathrm{T}$ cells, as well as non-transfected Jurkat $\mathrm{T}$ cells and $\mathrm{p} 8^{\mathrm{I}}$-transfected MT-2 cells. A significant amount of $\mathrm{p} 8^{\mathrm{I}}$ was transferred to the non-transfected cells [43]. Thus, $\mathrm{p} 8^{\mathrm{I}}$ provides an additional mechanism for virus transmission through increased conduit formation (Figure 4) along with transfer through virological synapses [87] and "viral biofilm" formation [88]. The capability of $\mathrm{p} 8^{\mathrm{I}}$ to inactivate and segregate $\mathrm{T}$ cells, as well as to enhance the formation of cellular conduits, protects the virus from immune recognition, thereby ensuring efficient virus propagation.

The large body of predominantly in vivo studies of $\mathrm{p} 12^{\mathrm{I}}$ and $\mathrm{p} 8^{\mathrm{I}}$ proteins points to the indispensable roles of these proteins in modulating the signaling pathways of host $\mathrm{T}$ cells. This modulation suppresses immune responses and compromises the capability of the infected organism to identify and eliminate HTLV-1. Therefore, these proteins help the virus to establish long persistence and, in some cases, cause malignant cell transformations. 


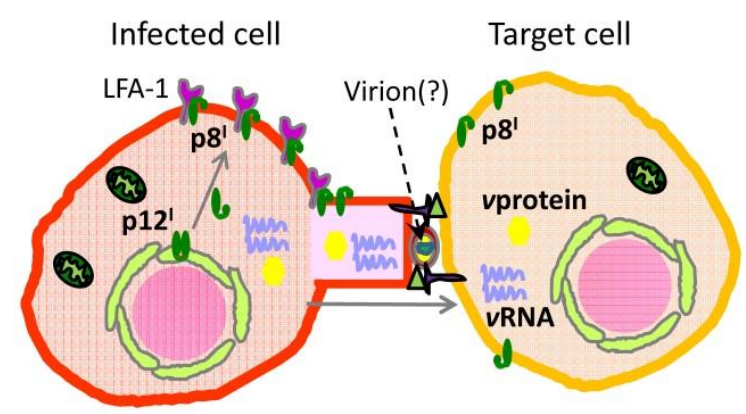

Figure 4. $\mathrm{p} 8^{\mathrm{I}}$ provides a mechanism for virus transmission through increased conduit formation: $\mathrm{p} 8 \mathrm{I}$ interacts with and enhances the clustering of lymphocyte function-associated antigen-1 (LFA-1) in the plasma membrane, and by doing so facilitates the contact between $\mathrm{T}$ cells. This results in the formation of conduits between infected and healthy cells, resulting in virus transmission. It is currently unknown whether this transmission occurs through a virion assembly.

\section{3. p13 ${ }^{\mathrm{II}}$ Protein and Its Role in the Control of Mitochondrial Apoptosis}

p13 II is encoded by the ORF-II of HTLV-1, and it corresponds to the C-terminal region of another $\mathrm{NSP}, \mathrm{p} 30^{\mathrm{II}}$, which has two nucleus localization/retention sequences (NLS's) in its $\mathrm{N}$ - and C-terminal regions and resides and functions in the nucleus [89-91]. $\mathrm{p} 13^{\mathrm{II}}$ might have only the C-terminal NLS (Figure 5). Initially, p13 ${ }^{\mathrm{II}}$ was thought to be a predominantly nuclear protein, as it was found in the nucleus of $\mathrm{p} 13^{\mathrm{II}}$-transfected HeLa cells [49]. Further studies demonstrated partial nuclear localization upon $\mathrm{p} 13^{\mathrm{II}}$ co-expression with the HTLV-1-encoded transcriptional regulator Tax protein $[89,92]$. In nuclear speckles, p13 ${ }^{\mathrm{II}}$ directly binds Tax [93], thus reducing Tax transcriptional activity and viral expression [92]. However, the role of $\mathrm{p} 13^{\mathrm{II}}$ as a nuclear protein is not discussed in detail herein, as it is beyond the scope of this review, which focuses on $\mathrm{p} 13^{\mathrm{II}}$ function in the IMM. It is currently known that $\mathrm{p} 13^{\mathrm{II}}$ has a mitochondrial targeting sequence (MTS), localizes in the IMM, and affects mitochondrial morphology and function [89,94-97]. A critical role for $\mathrm{p} 13^{\mathrm{II}}$ has been suggested by the finding that persistent viral infection failed to establish in rabbits inoculated with cells expressing $\mathrm{p} 13^{\mathrm{II}}$-deficient HTLV-1, but not in rabbits inoculated with cells expressing wild-type HTLV-1 [98].

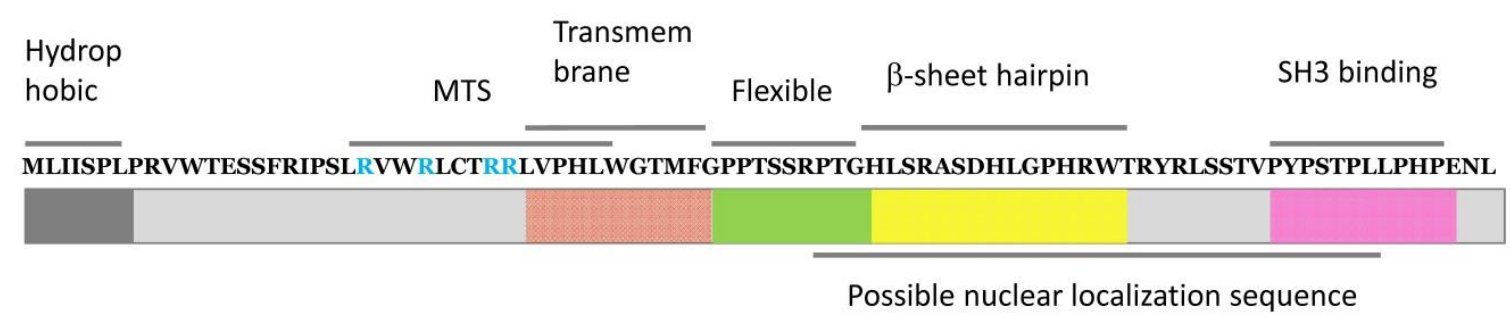

Figure 5. Amino acid sequence and domain architecture of $\mathrm{p} 13^{\mathrm{II}}$ protein: $\mathrm{p} 13^{\mathrm{II}}$ has hydrophobic $\mathrm{N}$-terminal followed by an amphipathic helix, which contains the mitochondrial targeting sequence (MTS); transmembrane helix; highly flexible region; predicted $\beta$-sheet region; SH3-binding sequence with PXXP motif; and possibly nuclear localization sequence. The arginines (R) in MTS are colored in blue.

p13 $13^{\text {II }}$ is a positively charged 87 -aa protein with multi-domain organization (Figure 5) $[94,95]$ composed of (i) a hydrophobic $\mathrm{N}$-terminus; (ii) an arginine-rich amphipathic $\alpha$ helix comprising residues 20-30 and including the MTS (LRVWRLCTRRLVPHL). (Note, however, that this MTS differs from the canonical MTS's, which are located at the N-terminal and cleaved after protein insertion in the IMM.) [99]; (iii) a transmembrane region composed of residues 31-41; (iv) a highly flexible region comprising residues $42-49$, which might serve as a hinge in the structure of folded $\mathrm{p} 13^{\mathrm{II}}$; (v) a predicted $\beta$-sheet hairpin region encompassing residues 60-75; and (vi) a C-terminal PXXP motif, 
which likely interacts with $\mathrm{SH} 3$ domains in signaling proteins, although such activities of $\mathrm{p} 13^{\mathrm{II}}$ have not been reported.

p13 ${ }^{\mathrm{II}}$ may have an NLS as well, which might adopt a conformation favorable for trafficking the protein to the nucleus under conditions that mask the MTS. Thus, p13 ${ }^{\mathrm{II}}$ could fulfill several cell-compartment-dependent functions; however, currently, this multi-functional role is only hypothetical $[89,100]$. The protein is highly conserved among viruses from distant geographical regions [94]. After its expression in the host cell, $\mathrm{p} 13^{\mathrm{II}}$ is trafficked to and inserts into the IMM, forming predominantly helical self-assemblies with molecular weights higher than that of a monomer with cation channel activity $[89,94,95,97,101,102]$. The current view is that $\mathrm{p} 13^{\mathrm{II}}$ is predominantly a potassium $\left(\mathrm{K}^{+}\right)$channel $[96,102]$.

It has been found that a synthetic construct of full-length $\mathrm{p} 13^{\mathrm{II}}$ localizes in the IMM of isolated energized rat liver mitochondria and triggers $\mathrm{K}^{+}$influx that results in modified mitochondrial morphology and swelling [96]. This effect was observed at $\mathrm{p} 13^{\mathrm{II}}$ concentrations between $5 \mathrm{nM}$ and $400 \mathrm{nM}$ and could be reversed by adding a protonophore that collapses IMM potential $\left(\Delta \Psi_{\mathrm{m}}\right)$. Furthermore, this study showed that $\mathrm{p} 13^{\mathrm{II}}$ causes IMM depolarization, which increases proton transport through the pumps of the electron transport chain (ETC) and thus restores membrane potential while increasing oxygen consumption. As a result of p13 $3^{\mathrm{II}}$-enhanced ETC activity, the level of reactive oxygen species (ROS) — which are produced in part in the mitochondria [103] and control cellular processes [104]—increased as well. Both IMM depolarization and elevated ROS concentration lead to a lowering of the threshold for the opening of the permeability transition pore [104-106] and ultimately triggering apoptosis. No such effects were observed for $\mathrm{p} 13^{\mathrm{II}}$ mutants with alanines instead of arginines in the MTS (Figure 5), which points to a key role for these positively charged residues. The importance of arginines in the MTS for $\mathrm{p} 13^{\mathrm{II}}$ function in the IMM has also been demonstrated in other studies in which these residues were substituted for glutamines, prolines, and leucines; by contrast, no effect on $\mathrm{p} 13^{\mathrm{II}}$ association with the IMM was observed [94,95].

An analogous effect of mitochondrial membrane depolarization, which is dependent on $\mathrm{p} 13^{\mathrm{II}}$ expression level and the presence of native arginines in the MTS, has been observed in HeLa cells [94]. Studies using p13 ${ }^{\mathrm{II}}$-transfected HeLa cells and Jurkat T cells transduced with a lentiviral vector expressing $\mathrm{p} 13^{\mathrm{II}}$ also showed enhanced ROS production [107]. However, unlike in isolated mitochondria [96], an increased ROS level was not recorded unless $\mathrm{p} 13^{\mathrm{II}}$ was expressed under conditions of glucose starvation [107]. The authors suggested that $\mathrm{p} 13^{\mathrm{II}}$ is sufficient to increase ROS levels, but at physiological glucose levels, the effect is counteracted by ROS scavengers. Strikingly, in both of the tumor cell lines, the expression of $\mathrm{p} 13^{\mathrm{II}}$ under glucose-deprived conditions significantly enhanced the probability of cell death (3- to 5-fold) compared with that associated with expression under conditions with normal glucose concentrations [107]. This outcome can be directly correlated to the increased level of ROS, as these species play critical roles in cell turnover [108].

At physiological levels, ROS are signaling molecules, whereas high ROS levels trigger cell death through apoptosis. More recent studies have found that the expression of wild-type $\mathrm{p} 13^{\mathrm{II}}$ activates primary $\mathrm{T}$ cells from their resting state, a change that depends on ROS concentration and $\mathrm{K}^{+}$ flux [107]. In general, ROS at upper physiological limits trigger the activation of T cells, leading to their division [108]. These findings might suggest that $\mathrm{p} 13^{\mathrm{II}}$ protein controls the turnover of infected $\mathrm{T}$ cells by eliminating those that undergo cancerous transformations while activating and promoting the division of those with regular morphology. Thus, the protein might increase the number of "normal" infected cells supporting virus proliferation and long-term persistence in HTLV-1 carriers. However, at present, the exact mechanisms through which $\mathrm{p} 13^{\mathrm{II}}$ affects cell physiology and pathology are poorly understood. The existing view is that the protein acts by modulating levels of mitochondrial ROS $[89,107]$. Lacking molecular details, the current functional model of IMM-associated p13 ${ }^{\mathrm{II}}$ in HTLV-1-infected cells assumes that the protein inserts into the IMM to form oligomeric channels. The channel activity of $\mathrm{p} 13^{\mathrm{II}}$ induces a $\Delta \Psi_{\mathrm{m}}$-dependent $\mathrm{K}^{+}$current and membrane depolarization. This effect is probably compensated by the enhanced activity of the ETC, leading to ROS formation. 
As a result, $\mathrm{T}$ cells undergo either activation at physiological ROS concentrations or apoptosis at toxic ROS levels (Figure 6) [96,102,107].

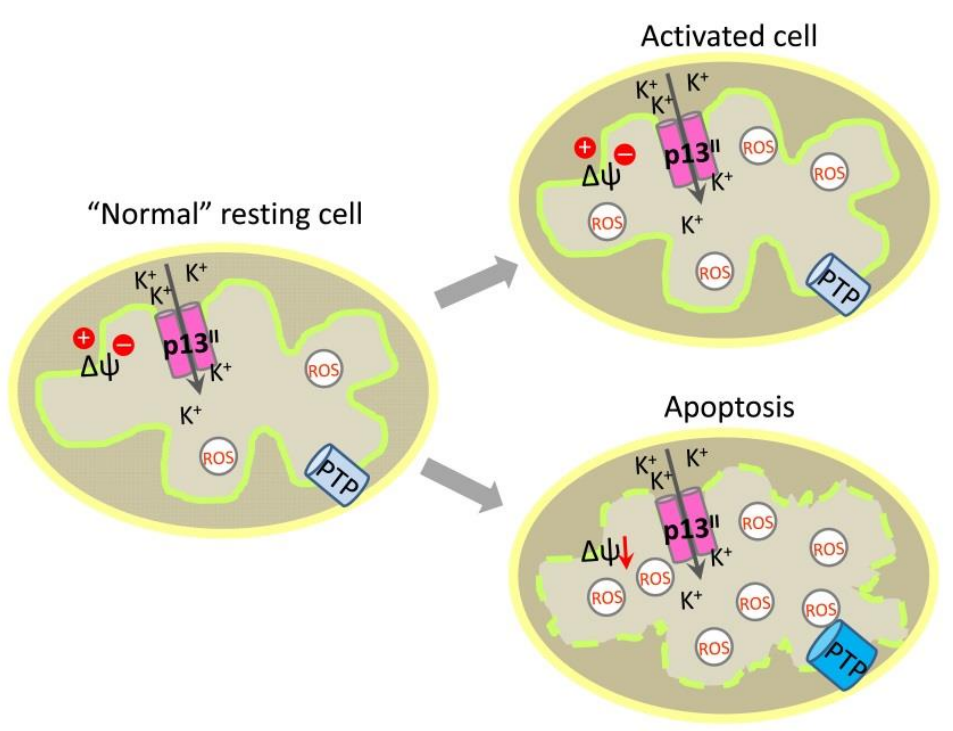

Figure 6. Model of $\mathrm{p} 13^{\mathrm{II}}$ function in T cells: $\mathrm{p} 13^{\mathrm{II}}$ forms oligomeric $\mathrm{K}^{+}$channel in inner mitochondrial membrane (IMM); $\mathrm{K}^{+}$influx affects $\Delta \Psi_{\mathrm{m}}$ and triggers processes that lead to ROS formation; at physiological ROS concertation, this leads to activation of the "normal" T cells; at very high toxic levels of ROS in transformed cells, this leads to apoptosis and cell death.

Alternative mechanisms for $\mathrm{p} 13^{\mathrm{II}}$-controlled T-lymphocyte death and survival also have been proposed. It has been suggested that $\mathrm{p} 13^{\mathrm{II}}$ is not an apoptotic factor per se but instead modulates other proteins on the pathway of apoptosis signaling $[89,109]$. One study showed that $\mathrm{p} 13^{\mathrm{II}}$-expressing Jurkat $T$ cells are sensitive to caspase-dependent ceramide- and FasL-induced apoptosis [109]. Ceramide is one of the key signaling molecules in apoptosis, and its formation can be induced by several stress factors, including oxidative stress and ROS [110]. FasL, a cytokine found predominantly in the cells of the immune system, is the ligand for the Fas receptor. FasL-Fas binding triggers apoptosis; FasL expression is also induced under conditions of cell stress [111]. Moreover, a reduction in FasL-induced apoptosis has been observed in $\mathrm{p} 13^{\mathrm{II}}$-expressing cells after treatment with a chemical inhibitor of Ras protein, which suggests that $\mathrm{p} 13^{\mathrm{II}}$ might specifically alter Ras-mediated apoptosis [109]. These findings could reveal a possible apoptotic mechanism of $\mathrm{p} 13^{\mathrm{II}}$ that aligns well with $\mathrm{p} 13^{\mathrm{II}}$ channel activity in the IMM leading to ROS formation.

\section{Roles of Tax, HBZ, and $\mathrm{p} 30^{\mathrm{II}}$ NSPs in HTLV-1 Life Cycle}

Because this review focuses on the function of HTLV-1-encoded NSPs $\mathrm{p} 8^{\mathrm{I}}, \mathrm{p} 12^{\mathrm{I}}$, and $\mathrm{p} 13^{\mathrm{II}}$ in the cellular membranes, only a brief outline of the roles of Tax, HBZ, Rex, and p30 ${ }^{\mathrm{II}}$, which are not membrane proteins, in HTLV-1 functioning in the infected cells is provided. Their properties and roles in the infected cells are described in excellent reviews published elsewhere [28,34,42,47,112-116].

Tax is a ca. $40 \mathrm{kDa}$ protein with a multi-domain organization that facilitates interactions with a range of cellular components in the nucleus and cytoplasm that result in modified cellular functions $[93,112]$. It regulates the expression of viral and cellular proteins; supports the proliferation of infected cells and accumulation of genetic modifications by precluding cell cycle arrest and inhibition of DNA damage repair; and induces cellular transformations. Tax is currently considered the most important protein for HTLV-1 oncogenesis [93,112,117,118].

HBZ is the only HTLV-1-encoded protein, which is expressed through the minus-strand transcription; is composed of an N-terminal activation domain, a central domain, and a basic leucine-zipper domain; and localizes in the nucleus [34,112,113]. HBZ antagonizes many of the 
activities of Tax, and its major functions include maintaining long-lasting asymptomatic infection, promotion of T-cell proliferation, inhibition of apoptosis and autophagy, and disrupting genomic integrity $[112,113]$. The protein is also implicated in all stages of ATLL progression.

Rex is a ca. $27 \mathrm{kDa}$ protein with several functional domains through which it binds to messenger RNA (mRNA) and interacts with both viral and host proteins [114,115]. As an mRNA binding protein, it plays the role of a post-translational regulator of HTLV-1 mRNA: Its most important functions are to transport mRNA from the nucleus to the cytoplasm and enhance the translation of viral structural proteins [114].

$\mathrm{p} 30^{\mathrm{II}}$ protein is the precursor of $\mathrm{p} 13^{\mathrm{II}}$ but has entirely nuclear localization. It prevents the export of Tax/Rex mRNA from the nucleus to the cytoplasm, thus acting as a downregulator of Tax and Rex and suppressor of viral replication $[49,116]$. p30 ${ }^{\mathrm{II}}$ binds specifically to and forms complexes with both Tax and Rex, and these interactions are stabilized by the presence of viral mRNAs.

\section{Conclusions}

This review focuses on the roles of the HTLV-1-encoded regulatory NSPs $\mathrm{p} 8^{\mathrm{I}}, \mathrm{p} 12^{\mathrm{II}}$, and $\mathrm{p} 13^{\mathrm{II}}$, which function in the organelles and plasma membranes of infected cells. Current knowledge suggests that these proteins aid the virus in escaping immune surveillance through mechanisms that modify multiple signaling cascades and regulate the cell cycle by inducing cell proliferation or apoptosis. Thus, these proteins are critical to viral adaptation, long survival, and proliferation. In-depth understanding of their mechanisms remains to be accomplished, however. It is currently unknown how these proteins interact with cellular components. Furthermore, multiple functions have been proposed for each of the three proteins, but the factors determining which function is initiated at which viral stage, or whether multiple functions are fulfilled in parallel, are poorly understood. Therefore, along with in-cell studies, a detailed explanation of protein structure and mechanism at the molecular level would be particularly helpful. Specifically, in vitro studies of recombinantly produced purified $\mathrm{p} 8^{\mathrm{I}}, \mathrm{p} 12^{\mathrm{II}}$, and $\mathrm{p} 13^{\mathrm{II}}$, which currently are extremely limited or even nonexistent, would both provide information about the structural bases of the interactions of these proteins with host membranes and proteins and clarify how the structures and membrane environment facilitate protein functions. This knowledge would greatly expand the general understanding of HTLV-1 mechanisms and inform the development of approaches to gain control of cellular dynamics and immune responses.

Funding: This research was funded in part by NIH grant R01 GM123779 and in part by NIH grant R03 AI137735. The APC was funded by the NIH grant R03 AI137735.

Acknowledgments: Grants R01 GM123779 from NIGMS and R03 AI137735 from NIAID are acknowledged. E.R.G. thanks the reviewers for their useful suggestions to improve the quality of this manuscript.

Conflicts of Interest: The authors declare no conflict of interest. The funding sponsors had no role in the design of the study; in the collection, analyses, or interpretation of data; in the writing of the manuscript, and in the decision to publish the results.

\section{References}

1. Gallo, R.C. The discovery of the first human retrovirus: HTLV-1 and HTLV-2. Retrovirology 2005, 2, 17. [CrossRef] [PubMed]

2. Yoshida, M. Discovery of HTLV-1, the first human retrovirus, its unique regulatory mechanisms, and insights into pathogenesis. Oncogene 2005, 24, 5931-5937. [CrossRef] [PubMed]

3. Matsuoka, M.; Jeang, K.T. Human T-cell leukaemia virus type 1 (HTLV-1) infectivity and cellular transformation. Nat. Rev. Cancer 2007, 7, 270-280. [CrossRef] [PubMed]

4. Barmak, K.; Harhaj, E.; Grant, C.; Alefantis, T.; Wigdahl, B. Human T cell leukemia virus type I-induced disease: Pathways to cancer and neurodegeneration. Virology 2003, 308, 1-12. [CrossRef]

5. Haabeth, O.A.; Tveita, A.A.; Fauskanger, M.; Schjesvold, F.; Lorvik, K.B.; Hofgaard, P.O.; Omholt, H.; Munthe, L.A.; Dembic, Z.; Corthay, A.; et al. How Do CD4(+) T Cells Detect and Eliminate Tumor Cells That Either Lack or Express MHC Class II Molecules? Front. Immunol. 2014, 5, 174. [CrossRef] [PubMed] 
6. Zhu, J.; Paul, W.E. CD4 T cells: Fates, functions, and faults. Blood 2008, 112, 1557-1569. [CrossRef] [PubMed]

7. Ratner, L. Adult T cell leukemia lymphoma. Front. Biosci. 2004, 9, 2852-2859. [CrossRef] [PubMed]

8. Richardson, J.H.; Edwards, A.J.; Cruickshank, J.K.; Rudge, P.; Dalgleish, A.G. In vivo cellular tropism of human T-cell leukemia virus type 1. J. Virol. 1990, 64, 5682-5687. [PubMed]

9. Taylor, G.P.; Matsuoka, M. Natural history of adult T-cell leukemia/lymphoma and approaches to therapy. Oncogene 2005, 24, 6047-6057. [CrossRef] [PubMed]

10. Verdonck, K.; Gonzalez, E.; Van Dooren, S.; Vandamme, A.M.; Vanham, G.; Gotuzzo, E. Human T-lymphotropic virus 1: Recent knowledge about an ancient infection. Lancet Infect. Dis. 2007, 7, 266-281. [CrossRef]

11. Cruickshank, J.K.; Rudge, P.; Dalgleish, A.G.; Newton, M.; McLean, B.N.; Barnard, R.O.; Kendall, B.E.; Miller, D.H. Tropical spastic paraparesis and human T cell lymphotropic virus type 1 in the United Kingdom. Brain 1989, 112 Pt 4, 1057-1090. [CrossRef]

12. Godoy, A.J.; Kira, J.; Hasuo, K.; Goto, I. Characterization of cerebral white matter lesions of HTLV-I-associated myelopathy/tropical spastic paraparesis in comparison with multiple sclerosis and collagen-vasculitis: A semiquantitative MRI study. J. Neurol. Sci. 1995, 133, 102-111. [CrossRef]

13. Levin, M.C.; Jacobson, S. HTLV-I associated myelopathy/tropical spastic paraparesis (HAM/TSP): A chronic progressive neurologic disease associated with immunologically mediated damage to the central nervous system. J. Neurovirol. 1997, 3, 126-140. [CrossRef] [PubMed]

14. Alves, C.; Dourado, L. Endocrine and metabolic disorders in HTLV-1 infected patients. Braz. J. Infect. Dis. 2010, 14, 613-620. [CrossRef]

15. Miyoshi, I.; Kubonishi, I.; Yoshimoto, S.; Akagi, T.; Ohtsuki, Y.; Shiraishi, Y.; Nagata, K.; Hinuma, Y. Type $\mathrm{C}$ virus particles in a cord T-cell line derived by co-cultivating normal human cord leukocytes and human leukaemic T cells. Nature 1981, 294, 770-771. [CrossRef] [PubMed]

16. Poiesz, B.J.; Ruscetti, F.W.; Gazdar, A.F.; Bunn, P.A.; Minna, J.D.; Gallo, R.C. Detection and isolation of type $\mathrm{C}$ retrovirus particles from fresh and cultured lymphocytes of a patient with cutaneous T-cell lymphoma. Proc. Natl. Acad. Sci. USA 1980, 77, 7415-7419. [CrossRef] [PubMed]

17. Inaba, S.; Sato, H.; Okochi, K.; Fukada, K.; Takakura, F.; Tokunaga, K.; Kiyokawa, H.; Maeda, Y. Prevention of transmission of human T-lymphotropic virus type 1 (HTLV-1) through transfusion, by donor screening with antibody to the virus. One-year experience. Transfusion 1989, 29, 7-11. [CrossRef] [PubMed]

18. Yamanouchi, K.; Kinoshita, K.; Moriuchi, R.; Katamine, S.; Amagasaki, T.; Ikeda, S.; Ichimaru, M.; Miyamoto, T.; Hino, S. Oral transmission of human T-cell leukemia virus type-I into a common marmoset (Callithrix jacchus) as an experimental model for milk-borne transmission. Jpn. J. Cancer Res. 1985, 76, 481-487. [PubMed]

19. Hino, S.; Yamaguchi, K.; Katamine, S.; Sugiyama, H.; Amagasaki, T.; Kinoshita, K.; Yoshida, Y.; Doi, H.; Tsuji, Y.; Miyamoto, T. Mother-to-child transmission of human T-cell leukemia virus type-I. Jpn. J. Cancer Res. 1985, 76, 474-480. [PubMed]

20. Kalyanaraman, V.S.; Sarngadharan, M.G.; Robert-Guroff, M.; Miyoshi, I.; Golde, D.; Gallo, R.C. A new subtype of human T-cell leukemia virus (HTLV-II) associated with a T-cell variant of hairy cell leukemia. Science 1982, 218, 571-573. [CrossRef] [PubMed]

21. Calattini, S.; Chevalier, S.A.; Duprez, R.; Bassot, S.; Froment, A.; Mahieux, R.; Gessain, A. Discovery of a new human T-cell lymphotropic virus (HTLV-3) in Central Africa. Retrovirology 2005, 2, 30. [CrossRef] [PubMed]

22. Wolfe, N.D.; Heneine, W.; Carr, J.K.; Garcia, A.D.; Shanmugam, V.; Tamoufe, U.; Torimiro, J.N.; Prosser, A.T.; Lebreton, M.; Mpoudi-Ngole, E.; et al. Emergence of unique primate T-lymphotropic viruses among central African bushmeat hunters. Proc. Natl. Acad. Sci. USA 2005, 102, 7994-7999. [CrossRef] [PubMed]

23. Gallo, R.C.; Montagnier, L. The discovery of HIV as the cause of AIDS. N. Engl. J. Med. 2003, 349, $2283-2285$. [CrossRef] [PubMed]

24. Murphy, E.L.; Fridey, J.; Smith, J.W.; Engstrom, J.; Sacher, R.A.; Miller, K.; Gibble, J.; Stevens, J.; Thomson, R.; Hansma, D.; et al. HTLV-associated myelopathy in a cohort of HTLV-I and HTLV-II-infected blood donors. The REDS investigators. Neurology 1997, 48, 315-320. [CrossRef] [PubMed]

25. Araujo, A.; Hall, W.W. Human T-lymphotropic virus type II and neurological disease. Ann. Neurol. 2004, 56, 10-19. [CrossRef] [PubMed] 
26. Yamamoto, N.; Okada, M.; Koyanagi, Y.; Kannagi, M.; Hinuma, Y. Transformation of human leukocytes by cocultivation with an adult T cell leukemia virus producer cell line. Science 1982, 217, 737-739. [CrossRef] [PubMed]

27. Chen, I.S.; Quan, S.G.; Golde, D.W. Human T-cell leukemia virus type II transforms normal human lymphocytes. Proc. Natl. Acad. Sci. USA 1983, 80, 7006-7009. [CrossRef] [PubMed]

28. Fukumoto, R. Human T-lymphotropic virus type 1 non-structural proteins: Requirements for latent infection. Cancer Sci. 2013, 104, 983-988. [CrossRef] [PubMed]

29. Edlich, R.F.; Arnette, J.A.; Williams, F.M. Global epidemic of human T-cell lymphotropic virus type-I (HTLV-I). J. Emerg. Med. 2000, 18, 109-119. [CrossRef]

30. Willems, L.; Hasegawa, H.; Accolla, R.; Bangham, C.; Bazarbachi, A.; Bertazzoni, U.; Carneiro-Proietti, A.B.; Cheng, H.; Chieco-Bianchi, L.; Ciminale, V.; et al. Reducing the global burden of HTLV-1 infection: An agenda for research and action. Antivir. Res. 2017, 137, 41-48. [CrossRef] [PubMed]

31. Gessain, A.; Cassar, O. Epidemiological Aspects and World Distribution of HTLV-1 Infection. Front. Microbiol. 2012, 3, 388. [CrossRef] [PubMed]

32. Uchiyama, T. Human T cell leukemia virus type I (HTLV-I) and human diseases. Annu. Rev. Immunol. 1997, 15, 15-37. [CrossRef] [PubMed]

33. Proietti, F.A.; Carneiro-Proietti, A.B.; Catalan-Soares, B.C.; Murphy, E.L. Global epidemiology of HTLV-I infection and associated diseases. Oncogene 2005, 24, 6058-6068. [CrossRef] [PubMed]

34. Kulkarni, A.; Bangham, C.R.M. HTLV-1: Regulating the Balance between Proviral Latency and Reactivation. Front. Microbiol. 2018, 9, 449. [CrossRef] [PubMed]

35. Biron, C.A.; Nguyen, K.B.; Pien, G.C.; Cousens, L.P.; Salazar-Mather, T.P. Natural killer cells in antiviral defense: Function and regulation by innate cytokines. Annu. Rev. Immunol. 1999, 17, 189-220. [CrossRef] [PubMed]

36. Lee, S.H.; Biron, C.A. Here today-Not gone tomorrow: Roles for activating receptors in sustaining NK cells during viral infections. Eur. J. Immunol. 2010, 40, 923-932. [CrossRef] [PubMed]

37. Chiang, S.C.; Theorell, J.; Entesarian, M.; Meeths, M.; Mastafa, M.; Al-Herz, W.; Frisk, P.; Gilmour, K.C.; Ifversen, M.; Langenskiold, C.; et al. Comparison of primary human cytotoxic T-cell and natural killer cell responses reveal similar molecular requirements for lytic granule exocytosis but differences in cytokine production. Blood 2013, 121, 1345-1356. [CrossRef] [PubMed]

38. Mortreux, F.; Gabet, A.S.; Wattel, E. Molecular and cellular aspects of HTLV-1 associated leukemogenesis in vivo. Leukemia 2003, 17, 26-38. [CrossRef] [PubMed]

39. Bangham, C.R. CTL quality and the control of human retroviral infections. Eur. J. Immunol. 2009, 39, 1700-1712. [CrossRef] [PubMed]

40. Manivannan, K.; Rowan, A.G.; Tanaka, Y.; Taylor, G.P.; Bangham, C.R. CADM1/TSLC1 Identifies HTLV-1-Infected Cells and Determines Their Susceptibility to CTL-Mediated Lysis. PLoS Pathog. 2016, 12, e1005560. [CrossRef] [PubMed]

41. Bangham, C.R. HTLV-1 infection: Role of CTL efficiency. Blood 2008, 112, 2176-2177. [CrossRef] [PubMed]

42. Bai, X.T.; Nicot, C. Overview on HTLV-1 p12, p8, p30, p13: Accomplices in persistent infection and viral pathogenesis. Front. Microbiol. 2012, 3, 400. [CrossRef] [PubMed]

43. Van Prooyen, N.; Gold, H.; Resen, V.; Schwartz, O.; Jones, K.; Ruscetti, F.; Lockett, S.; Gudla, P.; Venzon, D.; Franchini, G. Human T-cell leukemia virus type 1 p8 protein increases cellular conduits and virus transmission. Proc. Natl. Acad. Sci. USA 2010, 107, 20738-20743. [CrossRef] [PubMed]

44. Datta, A.; Silverman, L.; Phipps, A.J.; Hiraragi, H.; Ratner, L.; Lairmore, M.D. Human T-lymphotropic virus type-1 p30 alters cell cycle G2 regulation of T lymphocytes to enhance cell survival. Retrovirology 2007, 4, 49. [CrossRef] [PubMed]

45. Albrecht, B.; D'Souza, C.D.; Ding, W.; Tridandapani, S.; Coggeshall, K.M.; Lairmore, M.D. Activation of nuclear factor of activated T cells by human T-lymphotropic virus type 1 accessory protein p12(I). J. Virol. 2002, 76, 3493-3501. [CrossRef] [PubMed]

46. Banerjee, P.; Feuer, G.; Barker, E. Human T-cell leukemia virus type 1 (HTLV-1) p12I down-modulates ICAM-1 and -2 and reduces adherence of natural killer cells, thereby protecting HTLV-1-infected primary CD4+ T cells from autologous natural killer cell-mediated cytotoxicity despite the reduction of major histocompatibility complex class I molecules on infected cells. J. Virol. 2007, 81, 9707-9717. [PubMed] 
47. Azran, I.; Schavinsky-Khrapunsky, Y.; Aboud, M. Role of Tax protein in human T-cell leukemia virus type-I leukemogenicity. Retrovirology 2004, 1, 20. [CrossRef] [PubMed]

48. Fukumoto, R.; Andresen, V.; Bialuk, I.; Cecchinato, V.; Walser, J.C.; Valeri, V.W.; Nauroth, J.M.; Gessain, A.; Nicot, C.; Franchini, G. In vivo genetic mutations define predominant functions of the human T-cell leukemia/lymphoma virus p12I protein. Blood 2009, 113, 3726-3734. [CrossRef] [PubMed]

49. Koralnik, I.J.; Fullen, J.; Franchini, G. The p12I, p13II, and p30II proteins encoded by human T-cell leukemia/lymphotropic virus type I open reading frames I and II are localized in three different cellular compartments. J. Virol. 1993, 67, 2360-2366. [PubMed]

50. Van Prooyen, N.; Andresen, V.; Gold, H.; Bialuk, I.; Pise-Masison, C.; Franchini, G. Hijacking the T-cell communication network by the human T-cell leukemia/lymphoma virus type 1 (HTLV-1) p12 and p8 proteins. Mol. Asp. Med. 2010, 31, 333-343. [CrossRef] [PubMed]

51. Valeri, V.W.; Hryniewicz, A.; Resen, V.; Jones, K.; Fenizia, C.; Bialuk, I.; Chung, H.K.; Fukumoto, R.; Parks, R.W.; Ferrari, M.G.; et al. Requirement of the human T-cell leukemia virus p12 and p30 products for infectivity of human dendritic cells and macaques but not rabbits. Blood 2010, 116, 3809-3817. [CrossRef] [PubMed]

52. Collins, N.D.; Newbound, G.C.; Albrecht, B.; Beard, J.L.; Ratner, L.; Lairmore, M.D. Selective ablation of human T-cell lymphotropic virus type 1 p12I reduces viral infectivity in vivo. Blood 1998, 91, 4701-4707. [PubMed]

53. Albrecht, B.; Collins, N.D.; Burniston, M.T.; Nisbet, J.W.; Ratner, L.; Green, P.L.; Lairmore, M.D. Human T-lymphotropic virus type 1 open reading frame I p12(I) is required for efficient viral infectivity in primary lymphocytes. J. Virol. 2000, 74, 9828-9835. [CrossRef] [PubMed]

54. Franchini, G. Molecular mechanisms of human T-cell leukemia/lymphotropic virus type I infection. Blood 1995, 86, 3619-3639. [PubMed]

55. Feller, S.M.; Ren, R.; Hanafusa, H.; Baltimore, D. SH2 and SH3 domains as molecular adhesives: The interactions of Crk and Abl. Trends Biochem. Sci. 1994, 19, 453-458. [CrossRef]

56. Koch, C.A.; Erson, D.; Moran, M.F.; Ellis, C.; Pawson, T. SH2 and SH3 domains: Elements that control interactions of cytoplasmic signaling proteins. Science 1991, 252, 668-674. [CrossRef] [PubMed]

57. Trovato, R.; Mulloy, J.C.; Johnson, J.M.; Takemoto, S.; de Oliveira, M.P.; Franchini, G. A lysine-to-arginine change found in natural alleles of the human T-cell lymphotropic/leukemia virus type 1 p12(I) protein greatly influences its stability. J. Virol. 1999, 73, 6460-6467. [PubMed]

58. Edwards, D.; Fukumoto, R.; de Castro-Amarante, M.F.; Alcantara, L.C.; Galvao-Castro, B.; Washington Parks, R.; Pise-Masison, C.; Franchini, G. Palmitoylation and p8-mediated human T-cell leukemia virus type 1 transmission. J. Virol. 2014, 88, 2319-2322. [CrossRef] [PubMed]

59. Pise-Masison, C.A.; de Castro-Amarante, M.F.; Enose-Akahata, Y.; Buchmann, R.C.; Fenizia, C.; Parks, R.W.; Edwards, D.; Fiocchi, M.; Alcantara, L.C., Jr.; Bialuk, I.; et al. Co-dependence of HTLV-1 p12 and p8 functions in virus persistence. PLoS Pathog. 2014, 10, e1004454. [CrossRef] [PubMed]

60. Fukumoto, R.; Dundr, M.; Nicot, C.; Adams, A.; Valeri, V.W.; Samelson, L.E.; Franchini, G. Inhibition of T-cell receptor signal transduction and viral expression by the linker for activation of T cells-interacting p12(I) protein of human T-cell leukemia/lymphoma virus type 1. J. Virol. 2007, 81, 9088-9099. [CrossRef] [PubMed]

61. Nicot, C.; Mulloy, J.C.; Ferrari, M.G.; Johnson, J.M.; Fu, K.; Fukumoto, R.; Trovato, R.; Fullen, J.; Leonard, W.J.; Franchini, G. HTLV-1 p12(I) protein enhances STAT5 activation and decreases the interleukin-2 requirement for proliferation of primary human peripheral blood mononuclear cells. Blood 2001, 98, 823-829. [CrossRef] [PubMed]

62. Mulloy, J.C.; Crownley, R.W.; Fullen, J.; Leonard, W.J.; Franchini, G. The human T-cell leukemia/lymphotropic virus type 1 p12I proteins bind the interleukin-2 receptor beta and gammac chains and affects their expression on the cell surface. J. Virol. 1996, 70, 3599-3605. [PubMed]

63. Gaffen, S.L.; Liu, K.D. Overview of interleukin-2 function, production and clinical applications. Cytokine 2004, 28, 109-123. [CrossRef] [PubMed]

64. Malek, T.R.; Castro, I. Interleukin-2 receptor signaling: At the interface between tolerance and immunity. Immunity 2010, 33, 153-165. [CrossRef] [PubMed]

65. Smith, K.A.; Jacobson, E.L.; Emert, R.; Giordano, M.; Kovacs, E.; Mumneh, N.; Pilaro, F.; Sohn, T.; Warren, D. Restoration of immunity with interleukin-2 therapy. AIDS Read. 1999, 9, 563-572. [PubMed] 
66. Takemoto, S.; Mulloy, J.C.; Cereseto, A.; Migone, T.S.; Patel, B.K.; Matsuoka, M.; Yamaguchi, K.; Takatsuki, K.; Kamihira, S.; White, J.D.; et al. Proliferation of adult T cell leukemia/lymphoma cells is associated with the constitutive activation of JAK/STAT proteins. Proc. Natl. Acad. Sci. USA 1997, 94, 13897-13902. [CrossRef] [PubMed]

67. Bowman, T.; Garcia, R.; Turkson, J.; Jove, R. STATs in oncogenesis. Oncogene 2000, 19, 2474-2488. [CrossRef] [PubMed]

68. Cumaraswamy, A.A.; Gunning, P.T. Progress towards direct inhibitors of Stat5 protein. Horm. Mol. Biol. Clin. Investig. 2012, 10, 281-286. [CrossRef] [PubMed]

69. Johnson, J.M.; Nicot, C.; Fullen, J.; Ciminale, V.; Casareto, L.; Mulloy, J.C.; Jacobson, S.; Franchini, G. Free major histocompatibility complex class I heavy chain is preferentially targeted for degradation by human T-cell leukemia/lymphotropic virus type 1 p12(I) protein. J. Virol. 2001, 75, 6086-6094. [CrossRef] [PubMed]

70. Charles, A.J.; Travers, P.; Walport, M.; Shlomchik, M.J. (Eds.) The Major Histocompatibility Complex and Its Functions; Garland Science: New York, NY, USA, 2001.

71. Wieczorek, M.; Abualrous, E.T.; Sticht, J.; Alvaro-Benito, M.; Stolzenberg, S.; Noe, F.; Freund, C. Major Histocompatibility Complex (MHC) Class I and MHC Class II Proteins: Conformational Plasticity in Antigen Presentation. Front. Immunol. 2017, 8, 292. [CrossRef] [PubMed]

72. Chirathaworn, C.; Kohlmeier, J.E.; Tibbetts, S.A.; Rumsey, L.M.; Chan, M.A.; Benedict, S.H. Stimulation through intercellular adhesion molecule-1 provides a second signal for T cell activation. J. Immunol. 2002, 168, 5530-5537. [CrossRef] [PubMed]

73. Tanaka, Y.; Fukudome, K.; Hayashi, M.; Takagi, S.; Yoshie, O. Induction of ICAM-1 and LFA-3 by Tax1 of human T-cell leukemia virus type 1 and mechanism of down-regulation of ICAM-1 or LFA-1 in adult-T-cell-leukemia cell lines. Int. J. Cancer 1995, 60, 554-561. [CrossRef] [PubMed]

74. Fukudome, K.; Furuse, M.; Fukuhara, N.; Orita, S.; Imai, T.; Takagi, S.; Nagira, M.; Hinuma, Y.; Yoshie, O. Strong induction of ICAM-1 in human T cells transformed by human T-cell-leukemia virus type 1 and depression of ICAM-1 or LFA-1 in adult T-cell-leukemia-derived cell lines. Int. J. Cancer 1992, 52, 418-427. [CrossRef] [PubMed]

75. Ding, W.; Albrecht, B.; Kelley, R.E.; Muthusamy, N.; Kim, S.J.; Altschuld, R.A.; Lairmore, M.D. Human T-cell lymphotropic virus type 1 p12(I) expression increases cytoplasmic calcium to enhance the activation of nuclear factor of activated T cells. J. Virol. 2002, 76, 10374-10382. [CrossRef] [PubMed]

76. Hogan, P.G.; Chen, L.; Nardone, J.; Rao, A. Transcriptional regulation by calcium, calcineurin, and NFAT. Genes Dev. 2003, 17, 2205-2232. [CrossRef] [PubMed]

77. Chow, C.W.; Rincon, M.; Davis, R.J. Requirement for transcription factor NFAT in interleukin-2 expression. Mol. Cell. Biol. 1999, 19, 2300-2307. [CrossRef] [PubMed]

78. Ding, W.; Albrecht, B.; Luo, R.; Zhang, W.; Stanley, J.R.; Newbound, G.C.; Lairmore, M.D. Endoplasmic reticulum and cis-Golgi localization of human T-lymphotropic virus type 1 p12(I): Association with calreticulin and calnexin. J. Virol. 2001, 75, 7672-7682. [CrossRef] [PubMed]

79. Coe, H.; Michalak, M. Calcium binding chaperones of the endoplasmic reticulum. Gen. Physiol. Biophys. 2009, 28, F96-F103. [PubMed]

80. Kim, S.J.; Ding, W.; Albrecht, B.; Green, P.L.; Lairmore, M.D. A conserved calcineurin-binding motif in human T lymphotropic virus type $1 \mathrm{p} 12 \mathrm{I}$ functions to modulate nuclear factor of activated T cell activation. J. Biol. Chem. 2003, 278, 15550-15557. [CrossRef] [PubMed]

81. Rothermel, B.; Vega, R.B.; Yang, J.; Wu, H.; Bassel-Duby, R.; Williams, R.S. A protein encoded within the Down syndrome critical region is enriched in striated muscles and inhibits calcineurin signaling. J. Biol. Chem. 2000, 275, 8719-8725. [CrossRef] [PubMed]

82. Miskin, J.E.; Abrams, C.C.; Dixon, L.K. African swine fever virus protein A238L interacts with the cellular phosphatase calcineurin via a binding domain similar to that of NFAT. J. Virol. 2000, 74, 9412-9420. [CrossRef] [PubMed]

83. Shibasaki, F.; Kondo, E.; Akagi, T.; McKeon, F. Suppression of signalling through transcription factor NF-AT by interactions between calcineurin and Bcl-2. Nature 1997, 386, 728-731. [CrossRef] [PubMed]

84. Foyouzi-Youssefi, R.; Arnaudeau, S.; Borner, C.; Kelley, W.L.; Tschopp, J.; Lew, D.P.; Demaurex, N.; Krause, K.H. Bcl-2 decreases the free $\mathrm{Ca} 2+$ concentration within the endoplasmic reticulum. Proc. Natl. Acad. Sci. USA 2000, 97, 5723-5728. [CrossRef] [PubMed] 
85. Wulfing, C.; Davis, M.M. A receptor/cytoskeletal movement triggered by costimulation during T cell activation. Science 1998, 282, 2266-2269. [CrossRef] [PubMed]

86. Manz, B.N.; Groves, J.T. Spatial organization and signal transduction at intercellular junctions. Nat. Rev. Mol. Cell Biol. 2010, 11, 342-352. [CrossRef] [PubMed]

87. Taylor, J.M.; Brown, M.; Nejmeddine, M.; Kim, K.J.; Ratner, L.; Lairmore, M.; Nicot, C. Novel role for interleukin-2 receptor-Jak signaling in retrovirus transmission. J. Virol. 2009, 83, 11467-11476. [CrossRef] [PubMed]

88. Pais-Correia, A.M.; Sachse, M.; Guadagnini, S.; Robbiati, V.; Lasserre, R.; Gessain, A.; Gout, O.; Alcover, A.; Thoulouze, M.I. Biofilm-like extracellular viral assemblies mediate HTLV-1 cell-to-cell transmission at virological synapses. Nat. Med. 2010, 16, 83-89. [CrossRef] [PubMed]

89. Silic-Benussi, M.; Biasiotto, R.; Resen, V.; Franchini, G.; D'Agostino, D.M.; Ciminale, V. HTLV-1 p13, a small protein with a busy agenda. Mol. Asp. Med. 2010, 31, 350-358. [CrossRef] [PubMed]

90. Ghorbel, S.; Sinha-Datta, U.; Dundr, M.; Brown, M.; Franchini, G.; Nicot, C. Human T-cell leukemia virus type I p30 nuclear/nucleolar retention is mediated through interactions with RNA and a constituent of the 60 S ribosomal subunit. J. Biol. Chem. 2006, 281, 37150-37158. [CrossRef] [PubMed]

91. D'Agostino, D.M.; Ciminale, V.; Zotti, L.; Rosato, A.; Chieco-Bianchi, L. The human T-cell lymphotropic virus type 1 Tof protein contains a bipartite nuclear localization signal that is able to functionally replace the amino-terminal domain of Rex. J. Virol. 1997, 71, 75-83. [PubMed]

92. Andresen, V.; Pise-Masison, C.A.; Sinha-Datta, U.; Bellon, M.; Valeri, V.; Washington Parks, R.; Cecchinato, V.; Fukumoto, R.; Nicot, C.; Franchini, G. Suppression of HTLV-1 replication by Tax-mediated rerouting of the p13 viral protein to nuclear speckles. Blood 2011, 118, 1549-1559. [CrossRef] [PubMed]

93. Currer, R.; Van Duyne, R.; Jaworski, E.; Guendel, I.; Sampey, G.; Das, R.; Narayanan, A.; Kashanchi, F. HTLV tax: A fascinating multifunctional co-regulator of viral and cellular pathways. Front. Microbiol. 2012, 3, 406. [CrossRef] [PubMed]

94. Biasiotto, R.; Aguiari, P.; Rizzuto, R.; Pinton, P.; D’Agostino, D.M.; Ciminale, V. The p13 protein of human T cell leukemia virus type 1 (HTLV-1) modulates mitochondrial membrane potential and calcium uptake. Biochim. Biophys. Acta 2010, 1797, 945-951. [CrossRef] [PubMed]

95. D'Agostino, D.M.; Ranzato, L.; Arrigoni, G.; Cavallari, I.; Belleudi, F.; Torrisi, M.R.; Silic-Benussi, M.; Ferro, T.; Petronilli, V.; Marin, O.; et al. Mitochondrial alterations induced by the p13II protein of human T-cell leukemia virus type 1. Critical role of arginine residues. J. Biol. Chem. 2002, 277, 34424-34433. [CrossRef] [PubMed]

96. Silic-Benussi, M.; Cannizzaro, E.; Venerando, A.; Cavallari, I.; Petronilli, V.; La Rocca, N.; Marin, O.; Chieco-Bianchi, L.; Di Lisa, F.; D'Agostino, D.M.; et al. Modulation of mitochondrial K(+) permeability and reactive oxygen species production by the p13 protein of human T-cell leukemia virus type 1 . Biochim. Biophys. Acta 2009, 1787, 947-954. [CrossRef] [PubMed]

97. Silic-Benussi, M.; Marin, O.; Biasiotto, R.; D’Agostino, D.M.; Ciminale, V. Effects of human T-cell leukemia virus type 1 (HTLV-1) p13 on mitochondrial $\mathrm{K}+$ permeability: A new member of the viroporin family? FEBS Lett. 2010, 584, 2070-2075. [CrossRef] [PubMed]

98. Hiraragi, H.; Kim, S.J.; Phipps, A.J.; Silic-Benussi, M.; Ciminale, V.; Ratner, L.; Green, P.L.; Lairmore, M.D. Human T-lymphotropic virus type 1 mitochondrion-localizing protein p13(II) is required for viral infectivity in vivo. J. Virol. 2006, 80, 3469-3476. [CrossRef] [PubMed]

99. Omura, T. Mitochondria-targeting sequence, a multi-role sorting sequence recognized at all steps of protein import into mitochondria. J. Biochem. 1998, 123, 1010-1016. [CrossRef] [PubMed]

100. Sinet, F. Complex Splicing in the Human T-cell Leukemia Virus (HTLV) Family of Retroviruses: A Number of Proteins Play a Key Role in the Establishment and Maintenance of Viral Infection. BioSciences Master Reviews Ecole Normale Supérieure de Lyon. July 2013, pp. 1-10. Available online: http:/ /biologie.ens-lyon. $\mathrm{fr} /$ ressources/bibliographies (accessed on 8 November 2018).

101. Franchini, G.; Nicot, C.; Johnson, J.M. Seizing of T cells by human T-cell leukemia/lymphoma virus type 1. Adv. Cancer Res. 2003, 89, 69-132. [PubMed]

102. D'Agostino, D.M.; Silic-Benussi, M.; Hiraragi, H.; Lairmore, M.D.; Ciminale, V. The human T-cell leukemia virus type 1 p13II protein: Effects on mitochondrial function and cell growth. Cell Death Differ. 2005, 12 (Suppl. 1), 905-915. [CrossRef] [PubMed] 
103. Jensen, P.K. Antimycin-insensitive oxidation of succinate and reduced nicotinamide-adenine dinucleotide in electron-transport particles. II. Steroid effects. Biochim. Biophys. Acta 1966, 122, 167-174. [CrossRef]

104. Zorov, D.B.; Juhaszova, M.; Sollott, S.J. Mitochondrial reactive oxygen species (ROS) and ROS-induced ROS release. Physiol. Rev. 2014, 94, 909-950. [CrossRef] [PubMed]

105. Bernardi, P. Modulation of the mitochondrial cyclosporin A-sensitive permeability transition pore by the proton electrochemical gradient. Evidence that the pore can be opened by membrane depolarization. J. Biol. Chem. 1992, 267, 8834-8839. [PubMed]

106. Costantini, P.; Chernyak, B.V.; Petronilli, V.; Bernardi, P. Modulation of the mitochondrial permeability transition pore by pyridine nucleotides and dithiol oxidation at two separate sites. J. Biol. Chem. 1996, 271, 6746-6751. [CrossRef] [PubMed]

107. Silic-Benussi, M.; Cavallari, I.; Vajente, N.; Vidali, S.; Chieco-Bianchi, L.; Di Lisa, F.; Saggioro, D.; D'Agostino, D.M.; Ciminale, V. Redox regulation of T-cell turnover by the p13 protein of human T-cell leukemia virus type 1: Distinct effects in primary versus transformed cells. Blood 2010, 116, 54-62. [CrossRef] [PubMed]

108. Rustin, P. Mitochondria, from cell death to proliferation. Nat. Genet. 2002, 30, 352-353. [CrossRef] [PubMed]

109. Hiraragi, H.; Michael, B.; Nair, A.; Silic-Benussi, M.; Ciminale, V.; Lairmore, M. Human T-lymphotropic virus type 1 mitochondrion-localizing protein p13II sensitizes Jurkat T cells to Ras-mediated apoptosis. J. Virol. 2005, 79, 9449-9457. [CrossRef] [PubMed]

110. Mathias, S.; Pena, L.A.; Kolesnick, R.N. Signal transduction of stress via ceramide. Biochem. J. 1998, 335 Pt 3 , 465-480. [CrossRef]

111. Nagata, S. Fas ligand-induced apoptosis. Annu. Rev. Genet. 1999, 33, 29-55. [CrossRef] [PubMed]

112. Giam, C.Z.; Semmes, O.J. HTLV-1 Infection and Adult T-Cell Leukemia/Lymphoma-A Tale of Two Proteins: Tax and HBZ. Viruses 2016, 8, 161. [CrossRef] [PubMed]

113. Ma, G.; Yasunaga, J.; Matsuoka, M. Multifaceted functions and roles of HBZ in HTLV-1 pathogenesis. Retrovirology 2016, 13, 16. [CrossRef] [PubMed]

114. Nakano, K.; Watanabe, T. HTLV-1 Rex: The courier of viral messages making use of the host vehicle. Front. Microbiol. 2012, 3, 330. [CrossRef] [PubMed]

115. Baydoun, H.H.; Bellon, M.; Nicot, C. HTLV-1 Yin and Yang: Rex and p30 master regulators of viral mRNA trafficking. AIDS Rev. 2008, 10, 195-204. [PubMed]

116. Bai, X.T.; Baydoun, H.H.; Nicot, C. HTLV-I p30: A versatile protein modulating virus replication and pathogenesis. Mol. Asp. Med. 2010, 31, 344-349. [CrossRef] [PubMed]

117. Matsumoto, K.; Shibata, H.; Fujisawa, J.I.; Inoue, H.; Hakura, A.; Tsukahara, T.; Fujii, M. Human T-cell leukemia virus type 1 Tax protein transforms rat fibroblasts via two distinct pathways. J. Virol. 1997, 71, 4445-4451. [PubMed]

118. Tanaka, A.; Takahashi, C.; Yamaoka, S.; Nosaka, T.; Maki, M.; Hatanaka, M. Oncogenic transformation by the tax gene of human T-cell leukemia virus type I in vitro. Proc. Natl. Acad. Sci. USA 1990, 87, 1071-1075. [CrossRef] [PubMed]

(c) 2018 by the author. Licensee MDPI, Basel, Switzerland. This article is an open access article distributed under the terms and conditions of the Creative Commons Attribution (CC BY) license (http://creativecommons.org/licenses/by/4.0/). 